\title{
Sustainable Development Goals and the World's Leading Hotel Groups
}

\author{
By Peter Jones ${ }^{*} \&$ Daphne Comfort ${ }^{\dagger}$
}

\begin{abstract}
A number of trade organisations within the tourism and hospitality industry have argued that the industry can play a major role in contributing to the Sustainable Development Goals (SDGs). This paper examines if, and how, the world's leading ten hotel groups have begun to address the SDG's and offers some general reflections the industry's engagement with the SDGs. The paper reveals marked variations in the ways in which the world's leading hotel groups have begun to address the SDGs. As such, the authors suggest that the world's leading hotel groups have some way to go if they are to play a leading role in contributing to the SDGs. More generally, the authors suggest that the leading hotel groups are to fulfill that contribution they must focus more explicitly on the SDGs themselves, adopt a more comprehensive approach to drawing up their priorities for the SDGs, and address the issues of measurement, independent external assurance and the tensions between business imperatives and sustainability.
\end{abstract}

Keywords: Sustainable Development Goals, Leading Hotel Groups, Business Priorities, Reporting, External Assurance.

\section{Introduction}

The United Nations (UN) Sustainable Development Goals (SDGs), launched in 2015, 'are the blueprint to achieve a better and more sustainable future for all' and they look to 'address the global challenges we face, including those related to poverty, inequality, climate, environmental degradation, prosperity, and peace and justice' (United Nations 2018). At the same time, the United Nations Global Compact (2018) argued that meeting these goals 'will take an unprecedented effort by all sectors in society' but emphasised that 'business has to play a very important role in the process.' The tourism and hospitality industry is a major player in the global economy, and a number of its trade organisations have emphasised the role the industry can play in contributing to the successful achievement of the SDGs such as The World Tourism Organisation and the United Nations Global Compact Network Spain (2016), for example, argued 'tourism is one of the most dynamic and far reaching economic sectors, and can make a decisive contribution to the achievement of the SDGs.' Further, the World Tourism Organisation and the United Nations Development Programme (2017) 'are committed to inspire leadership and facilitate collaboration to inspire stakeholders to advance the contribution of tourism to the SDGs.' At the same time the International Tourism Partnership suggested that the SDGs 'send out a clear call to action for the wider industry about the critical importance of using

\footnotetext{
*Professor of Management, University of Gloucestershire, U.K.

${ }^{\dagger}$ Daphne Comfort, Research Administrator, University of Gloucestershire, U.K.
} 
the UN SDGs as a focal point to drive responsible business in hospitality' (International Tourism Partnership 2018).

From outside the industry, Jones, Hillier and Comfort (2017) argued 'potentially the leading companies within the tourism and hospitality industry are in a powerful position to contribute to the successful achievement of the SDGs' but that in looking to make a meaningful contribution they needed to 'address a number of challenges.' These challenges included identifying priorities, the decision to develop new sustainability strategies specifically to meet SDGs or to map existing strategies on to the SDGs and the tensions between sustainability and commitments to business development and continuing economic growth. With these thoughts in mind, this paper examines if, and how, the world's leading ten hotel groups have begun to address the SDGs and offers some general reflections on the industry's engagement with the SDGs.

The main body of the paper begins with an outline of the frame of reference for the paper, which outlines the characteristics of the top ten hotels and the method of enquiry, which draws its information from a search of the hotel's corporate websites. This is followed by the findings of this search, which review the different ways in which the selected hotels addressed the SDGs. The authors then offer a reflective discussion, which raises issues interpretation and terminology, business priorities, metrics and measurement, business reporting and communication and the relationships and tensions between business imperatives and sustainability.

\section{Frame of Reference and Method of Enquiry}

In an attempt to undertake an exploratory review of if, and how, the world hotel industry has begun to address the SDGs the 'Top Ten Leading Hotel Groups' (Tourism Review 2017), as ranked by revenue, were selected for study. The ten hotel groups are given in Table 1. As the largest players within the hotel industry, the selected companies might be expected to reflect innovative thinking in their approach to the SDGs.

Table 1. Top Ten Leading Hotel Groups

\begin{tabular}{|c|l|c|c|}
\hline & \multicolumn{1}{|c|}{ Hotel } & \multicolumn{1}{|c|}{$\begin{array}{c}\text { World Capacity } \\
\text { (in Beds) }\end{array}$} & $\begin{array}{c}\text { Number of } \\
\text { Countries }\end{array}$ \\
\hline 1 & Marriott International & $1,200,000$ & 110 \\
\hline 2 & AccorHotels & 570,000 & 96 \\
\hline 3 & Wyndham Hotels and Resorts & 723,000 & 75 \\
\hline 4 & Hilton & 894,000 & 103 \\
\hline 5 & Hyatt Hotels Corporation & 182,000 & 54 \\
\hline 6 & $\begin{array}{l}\text { Jin Jiang International Hotel } \\
\text { Management Company }\end{array}$ & 800,000 & 67 \\
\hline 7 & Shangri-La Hotels and Resorts & 38,000 & 22 \\
\hline 8 & Melia Hotels International & 99,000 & 40 \\
\hline 9 & Intercontinental Hotel Group & 776,000 & 100 \\
\hline 10 & NH Hotel Group & 53,000 & 30 \\
\hline
\end{tabular}

Source: Various Trade Sources 
The hotel groups listed in Table 1 had some 5.3 million bedrooms and while many had a global reach, some operated more on a regional international level. While comprehensive market share data, covering all the selected hotel groups, is not available, Marriot International, has approximately 14\% of the market, while the corresponding figures for Hilton, Hyatt Hotel Corporation and Shangri-La Hotels and Resorts, are 7\%, 2.5\% and 1.25\% respectively (MarketWatch 2018).

Marriott International is a US multinational hospitality company, headquartered in Bethesda, Maryland, and owns some 6,500 properties in over 120 countries. AccorHotels is a French multinational company that owns, manages and franchises hotels, resorts and vacation properties and operates over 4,000 hotels in 100 countries. The Wyndham Hotels and Resort is the world's largest hotel franchise company and trades as a number of brands, including Wyndham, Ramada and Days Inn, in over 70 countries. Hilton is a major US based Hospitality Company, and either owns, manages or franchises over 570 hotels and resorts in 85 countries. The Hyatt Hotel Corporation is headquartered in Chicago, US, and manages and franchises over 700 hotels, resorts and vacation properties in some 50 countries. The Jin Jiang Hotel Management Company is a Chinese state owned tourism and hospitality company, and while it has some 6,000 hotels in over 60 countries, its main operating base is in China. Shangri-La Hotels and Resorts, which has positioned itself at the luxury end of the market, is a Hong Kong based multinational company and has some 100 hotels and resorts in Africa, Asia, Europe, North America and the Middle East. Melia Hotels International, a Spanish based hotel chain, is the market leader in resort and urban hotels within Spain and operates 375 hotels in 40 other countries. The InterContinental hotel Group is a UK based multinational hospitality group and operates some 5,000 hotels across almost 100 countries. The NM Hotel group is a Spanish based hotel chain and has some 375 hotels in 29 countries, principally in Europe and Latin America.

Hotel groups have employed a range of methods to report on their sustainability commitments and achievements, but publication on corporate websites has become the most popular and the most accessible reporting mechanism (Morhardt 2009). With this in mind, the authors conducted an Internet search for information, using the phrase 'Sustainable Development Goals' and the names of each of the selected hotel groups. This search was conducted in December 2018, using Google as the search engine. The information obtained from this search process provided the empirical information for this paper. The specific examples and selected quotations drawn from the corporate websites are used for illustrative purposes, with the principal aim being to review the ways in which the selected hotel groups addressed the SDGs. The case study is based on information that is in the public domain and the authors took the considered view that they did not need to contact the selected hotel groups to obtain formal permission to use this information prior to conducting their research. 


\section{Findings}

The selected hotel groups addressed the SDGs in a variety of ways. Table 2 provides a summary of number of SDGs publicly addressed by each hotel group and reveals that while two of the selected companies, Marriott International and Hilton, addressed all 17 SDGs, two of the companies, Shangri-La Hotels and Resorts and the NH Hotel Group, addressed none of them. At the individual level, SDG 8, namely Decent Work and Economic Growth, was the most commonly addressed of the SDGs. In his 'Executive Statement' for Hilton's 2017 Corporate Social Responsibility Report, Christopher J. Nasetta, President and Chief Executive Officer, for example, suggested 'at Hilton, we're more and more inspired every day to use our hospitality for good and as a truly global company, we are serious about our role in helping the international community reach the UN SDGs' (Hilton 2018). Hilton reported that the company had properties in over 100 countries and that the company was looking 'to harness our global hospitality mission to help drive local solutions in the communities, where we operate, aligning our action to the SDGs' (Hilton 2018).

Hilton addressed all 17 of the SDGs by aligning each of them to specific 'targets.' In addressing SDG1, for example, Hilton's 'target alignment' stressed its commitment to 'eradicate extreme poverty', 'implement social protection systems' and to provide 'equal rights to economic resources' (Hilton 2018). More specifically, Hilton reported being 'committed to opening doors for 1 million young people by 2019 to connecting, preparing or employing them' and being 'committed to connecting, preparing or employing refugees in Europe' (Hilton 2018). Further, Hilton reported being 'on track to reach our 2019 pledge to open doors to 1 million young people' (Hilton 2018) and that as a founding member of the Global Apprenticeship Network, the company had supported over 2,500 apprenticeships and encouraged training legislation in Egypt, Namibia, Saudi Arabia, Turkey, UK and US.

Table 2. SDGs Addressed by Each Hotel

\begin{tabular}{|l|l|c|c|}
\hline & \multicolumn{1}{|c|}{ Hotel } & Number of SDGs & $\begin{array}{c}\text { Percentage of } \\
\text { Total }\end{array}$ \\
\hline 1 & Marriott International & 17 & $100 \%$ \\
\hline 2 & AccorHotels & 10 & $59 \%$ \\
\hline 3 & Wyndham Hotels and Resorts & 10 & $59 \%$ \\
\hline 4 & Hilton & 17 & $100 \%$ \\
\hline 5 & Hyatt Hotels Corporation & 8 & $47 \%$ \\
\hline 6 & $\begin{array}{l}\text { Jin Jiang International Hotel } \\
\text { Management Company }\end{array}$ & 0 & $0 \%$ \\
\hline 7 & Shangri-La Hotels and Resorts & No specific details & Not applicable \\
\hline 8 & Melia Hotels International & 7 & $41 \%$ \\
\hline 9 & Intercontinental Hotel Group & No specific details & Not applicable \\
\hline 10 & NH Hotel Group & & \\
\hline
\end{tabular}


Hilton's target alignment to SDG 6 embraced 'access to safe drinking water', 'adequate sanitation and hygiene' and 'water resource management' (Hilton 2018). In evidencing these targets, Hilton reported reducing water consumption by $20 \%$ per square foot of hotel space since 2008, signing on for the UN's Chief Executive Officer Water Mandate and launching a number of global water stewardship pilot schemes in high risks regions in the US, South Africa and China. Hilton identified specific target alignments in addressing SDG13, namely to improve education and awareness of climate change and to promote mechanisms for climate change-related planning. In addressing these targets, Hilton reported reducing carbon emissions by $30 \%$ per square foot of hotel space and energy consumption by $20 \%$ per square foot of hotel space since 2008, activating 1,800 environmental projects in 1,000 communities during Earth Week in 2017. Hilton (2018) also reported being the first major hospitality brand to have 'science-based greenhouse gas targets approved by the Science Based Targets initiative.'

Additionally, the Conrad N. Hilton Foundation, which funds not for profit organisations working to improve the lives of disadvantaged and vulnerable people throughout the world, illustrated some of its work in contributing to the SDGs. On the one hand, the Foundation outlined its belief that philanthropy has an important role to play in supporting the SDGs through advocacy, facilitating implementation, helping to measure success and in training the next generation of leaders capable of promoting evidence-based solutions that address human development, health and economic and environmental needs at the core of the SDGs' (Hilton Foundation 2018a). On the other hand, the Conrad N. Hilton Foundation has argued that 'people underestimate the universality of the global goals, assuming they only apply to developing countries' whereas the 'we at the Conrad N. Hilton Foundation, firmly understands the relevance of the goals at the domestic level' (Hilton Foundation 2018 b).

The InterContinental Hotels Group (IHG) claimed 'our business supports several SDGs, from reducing poverty and hunger through our economic multiplier effect, to providing quality education via our IHG Academy and decent work to hundreds of thousands of colleagues globally, and combating climate change through the IHG Green Engage system' (IHG 2018). More specifically, IHG targeted seven of the SDGs, namely SDGs 6, 8. 10,11, 12, 13 and 17, 'where we believe we can have the biggest impact' (IHG 2018). In addressing SDG 8, for example, IHG (2018) suggested 'with more than 5,300 hotels globally and a further 1,600 in the pipeline, we can create a positive economic impact by providing jobs for local people' and reported that 'during 2017, 2,133 IHG Academy programmes in 75 countries, benefitted 13,633 participants improving their employability in the hospitality industry.' In contributing to SDG 11, IHG claimed 'our hotels provide critical economic stimulation in the communities within which they operate, including in developing countries' and that 'we ensure our hotels are prepared and able to play an active role in supporting those impacted by disasters, helping local communities get back on their feet quickly' (IHG 2018).

In 2018 Marriott International (2018) launched 'Serve 360', which the company claimed was 'guided by the UN SDGs.' Ray Bennett, Chief Global 
Officer, Global Operations at Marriott International, argued 'as the global hospitality leader with properties and associates across 125 countries and territories, Marriott International has a global responsibility and unique opportunity to be a force for good - from helping to reduce carbon and water use to providing our associates with human trafficking awareness training' (Marriott International 2018). Four 'priority areas', namely 'advancing the resiliency and development of our communities'; 'reducing the company's environmental impacts, sourcing responsibly and operating sustainable hotels'; 'helping people prepare for jobs in the hospitality industry'; and 'creating a safe and welcoming world for associates and travellers alike.'

In addressing reducing environmental impacts, for example, the company is looking to 'minimize our environmental footprint by sustainably managing our energy and water use, reducing our waste and carbon emissions and increasing the use of renewable energy. We employ innovative technologies to plan, implement, track and communicate how we operate responsibly to mitigate climate-related risk, benefiting our business and the communities in which we operate' (Marriott International 2018). More specifically, the company has committed to reducing water use by $15 \%$, carbon emissions by $30 \%$ waste by $45 \%$ and food waste by $50 \%$, all by 2025 , to train all associates to recognise the signs of human trafficking and to embed human rights criteria in recruitment and sourcing policies.

AccorHotels (2016) reported looking to contribute to the SDGs through its 'Planet 21' sustainable development programme. This programme is built around four 'strategic priorities', namely to 'work with its employees, involve its customers, innovate with its partners and work with local communities' (AccorHotels 2016). The company listed 'key achievements' (AccorHotels 2016) from the programme under four headings, namely, planting for the planet, the fight against the sexual exploitation of children, eco-design and sustainable food. In evidencing the first of these achievements, the company reported 'at AccorHotels, we ask our customers to reuse their towels. Savings made on water and energy are used to fund tree planting. One tree is planted every minute' (AccorHotels 2016). In promoting healthy and sustainable food, AccorHotels reported its commitment to 'offering healthy, balanced and high quality food' including 'local products' and 'products grown in our kitchen gardens' as well as 'reducing food waste' and 'banning the use of overfished species in our restaurants' (AccorHotels 2016).

More generally, under the banner 'Planet 21 Research' AccorHotels (2016) asserted its belief 'that it is our duty to help spread knowledge and promote the progress of all stakeholders in the hotel industry - both businesses and guests' and that with this in mind 'we launched Planet 21 Research, a platform for sharing knowledge about sustainable development in the hotel industry.' An examination of the company's socio-economic footprint in 2016 revealed that AccorHotels supported '880,000 jobs and mainly creates wealth in our host countries' AccorHotels 2016). A study of the environmental footprint of AccorHotels, conducted in 2011, covered the entire life cycle of the company's activities. This study revealed that the five major environmental impacts were energy consumption, water consumption, waste production, climate change and water 
eutrophication. The company used the study to encourage, educate and empower its employees to initiate new ideas that reduce its environmental impacts.

In his Chairman and Chief Executive Officer's 'Message' to accompany the Wyndham Hotel and Resorts' 2016-2017 Corporate Social Responsibility Report, Stephen P. Holmes claimed, 'with a goal of reaching one million people by 2025 in support of the UN Sustainable Development Goals, to date we have enhanced the lives of over 300,000 people through our CSR programs' (Wyndham Hotels and Resorts 2018). Wyndham Hotels and Resorts aligned its material Corporate Social Responsibility goals to ten of the SDGs, namely SDGs 1, 2, 3 4, 5, 6, 8, 13, 15 and 17. In aligning the company's targets with SDG 15, for example, the aim was to 'promote and expand best practices for biodiversity protection across our properties' and to 'partner with suppliers to make a meaningful impact to protect forests' (Wyndham Hotels and Resorts 2018). The corresponding targets for SDG 17 were to 'continue to advance sustainable development through active participation in industry initiatives with the World Travel and Tourism Council, International Tourism Partnership, Department of Energy, and other global partners' (Wyndham Hotels and Resorts 2018).

The Hyatt Hotel Corporation claimed 'our corporate responsibility work supports the mission of the UN SDGs' (Hyatt 2018). The company's corporate responsibility strategy embraces six key sets of issues, namely, 'our people', 'our communities', 'human rights', 'our planet', 'responsible sourcing' and 'responsible seafood', each of these sets of issues is aligned to a number of the SDGs. Hyatt's commitment to 'our people', for example, is aligned to SDG's 5, 8 and 10, the company's commitment to 'our planet' is aligned to SDGs 6, 712 , and 13 and the commitment to responsible sourcing is aligned to SDGs 8, 12, 14 and 15 (Hyatt 2018). More specifically, the Hyatt's (2018) commitment to 'our planet' includes setting goals to reduce energy and water consumption and greenhouse gas emissions at its hotels, pursuing a variety of waste management and recycling strategies and building a culture of environmental stewardship amongst hotel owners and developers.

Melia Hotels International published its 'Global Corporate Social Responsibility Model' in 2015, which is based around six key principles, namely 'human rights and childhood', 'employability', 'local development and the fight against climate change', 'university and knowledge sharing', 'culture', and 'leadership and reputation' (Melia Hotels International 2018). Further, the company claimed that it had integrated the SDGs that a hotel company could help to support with its Corporate Social Responsibility Model' (Melia Hotels international 2018). More specifically Melia Hotels International (2018) claimed that the integration of the SDGs into its Corporate Social Responsibility Model would, inter alia, 'ensure a consistent management model that seeks continuous improvement', 'promote a model of responsible management in the value chain' and 'make the fight against climate change a key objective in hotel management.'

The NH Hotels Group (2018) claimed that the SDGs had been used along with other 'criteria', including the ten principles of the UN Global Reporting Compact and the G4 guidelines of the Global Reporting Initiative for Sustainability Reporting, to prepare its 2017 Annual Report. Here, the focus is on 
the 'SDGs in which NH Hotel Group has a direct and indirect impact' but the company's Annual Report offers no explicit treatment of its achievements against the SDGs (NH Hotels Group 2018). Finally while the Jin Jiang International Hotel Management Company published an 'Environmental Social and Governance Report' (Jin Jiang Hotels 2017) and Shangri-La Hotels provided some information on its 'Corporate Social Responsibility Focus Areas' (Shangri-La 2018), neither made any reference to the SDGs.

\section{Discussion}

The findings reveal marked variation in how the selected leading hotel groups have begun to address the SDGs. One group, Hilton, directly addressed all 17 SDGs, while InterContinental Hotel Group specifically targeted seven of the SDGs. Some of the hotel groups claimed that their corporate sustainability goals and targets had been aligned with the SDGs, others suggested that the SDGs had been guide for and/or integrated into development of their sustainability strategies, while two of the hotel groups made no reference whatsoever to the SDGs. That said, five sets of issues merit reflection and discussion, namely:

1. interpretation and terminology,

2. business priorities for the SDG's,

3. metrics and measurement,

4. business reporting and communication, and

5. the relationships and tensions between business imperatives and sustainability.

\section{Interpretation and Terminology}

Firstly, there are issues of interpretation and terminology. The majority of the selected hotel groups do not explicitly address the SDGs, rather they claim to have aligned their sustainability goals to the SDGs or to have integrated the SDGs into these strategies. Further, this process of alignment has been pursued in a general rather than a specific manner, and there has been little or no attempt to directly map corporate goals and targets to specific SDGs. Where hotel groups claim to have aligned a relatively small number of key corporate priorities to the SDGs, for example, the link to the specific SDGs can be seen to lack clarity. As such, it will be difficult for the hotel groups that have adopted this alignment or integration approach to assess how they are contributing to specific SDGs. On the one hand, such contributions become part of wider corporate contributions to sustainability and on the other this approach does not suggest that the majority of the selected hotel groups are 'using the UN SDGs as a focal point to drive responsible business in hospitality' (International Tourism Partnership 2018). More generally, Sultana (2018) expressed surprise at the choice of the term 'sustainable development', which she described as being 'at the heart of this new framework of titled SDGs.' Surprise, because she argued that 'sustainable development has been very 
contested, conflictual and contradictory in definition and reality since its uptake in the 1980's' and that 'sustainable development can mean anything to anybody' (Sultana 2018).

\section{Business Priorities for the SDG's}

Secondly, issues about priorities can be identified at two levels. As outlined above, some of the selected hotel groups have chosen to target, either directly or indirectly, a number of SDGs that they argue are aligned with their corporate goals and business strategies and where they feel they can make the most valuable contribution to the SDGs. More generally, this approach has been called into question in that PWC (2018) surveyed some 470 companies 'to investigate how they were reflecting the SDGs' and argued that 'many companies are engaging at a more superficial level.' This survey revealed that many companies 'are failing to prioritise goals that need corporate support the most and to address those that could cause the biggest problems in the future if left unchecked' and suggested the 'failure to consider the local context can also put companies at a disadvantage as they seek to do business around the world' (PWC 2018). At the same time, PWC (2018) argued that prioritisation 'also requires a longer-term vision of, and approach to, business growth strategy and planning than some companies are used to employing. To have that longer term perspective requires an understanding of the risks that a company could face if the underlying issues that the SDGs represent are not solved, and also of the opportunities that adapting products and services towards the innovations and solutions could offer.'

More generally, Moseley (2018) suggested that there is little evidence of the strategic prioritisation of the SDGs within the business community. In many ways, climate change is a cross cutting issue and its potentially damaging impacts may threaten the achievement of all the SDGs. The UN Framework Convention on Climate Change (2018), for example, claimed 'climate change presents the single biggest threat to sustainable development everywhere and its widespread, unprecedented impacts disproportionately burden the poorest and most vulnerable' and argued 'urgent action to halt climate change and deal with its impacts is integral to the successful implementation of the Sustainable Development Goals.' In a similar vein, in identifying environmental goals in the SDGs, Liverman (2018) reported that 'climate change has been identified as the one stress that could undermine the other environmental goals, as well as those on poverty or health' but questioned 'how well do the SDGs address the climate change challenge?'

\section{$\underline{\text { Metrics and Measurement }}$}

Thirdly, there are issues about measurement and metrics. At one level, there are issues about the data that is required to measure progress, the collection of such data and the mechanisms and procedures that will need to be established in order to monitor progress. At the local level, for example, Sultana (2018) argued local data are often not collected, or are not collected properly, are frequently 
inaccurate and are expensive to collect.' More generally, the dominant approach to the measurement and monitoring of the SDGs is to identify indicators for each SDG but Bali Swain (2018) argued that 'this approach if not flawed is inadequate' not least, in that it ignores the complex interrelationships between some of the SDGs. At the same time, the UN Division for Sustainable Development Goals (2018) acknowledged 'many important issues, such as gender equality, health, sustainable consumption and production, and nutrition, cut across goals and targets. The goals and targets are themselves interdependent, and must be pursued together, since progress in one area often depends on progress in other areas.'

More critically, Liverman (2018) claimed that the expansion in the number of goals and targets especially as indicators are developed for measuring progress towards targets, will add even more calculation, monitoring and quantification to the process of evaluating development' and that 'this is evident in the many calls to take advantage of new technologies for creating social and environmental indicators.' This in turn led her to claim 'this can result in overly narrow assessments that direct policy towards quantifiable outcomes rather than broader but harder to measure social needs' (Liverman 2018). Under the banner, 'should we dance with development metrics?' Moseley (2018) questioned the value of engaging with development metrics and argued that the SDGs represent what is wrong with development, both in their conception and in what they measure and do not measure.' Further, Nightingale (2018) suggested that 'for the SDGs to be effective, they need to go beyond simple statistics to account for how situated, performative aspects of life evolve, rather than as they are.'

\section{Business Reporting and Communication}

Fourthly, there are issues about reporting. More specifically, if the major hotel groups are to contribute to the SDGs they will need to integrate their achievements into their reporting processes. The SDG Compass, for example, emphasised to companies that 'It is important to report and communicate on your progress against the SDGs continuously in order to understand and meet the needs of your stakeholders' (Global Reporting Initiative/United Nations Global Compact/World Business Council for Sustainable Development (2015)). There are a number of elements within the sustainability reporting process but external assurance, a procedure employed to provide confidence in the accuracy and reliability of the reporting process, is widely seen to be a central element. However, in their review of how the world's leading hotel companies publicly communicate their approach to sustainability, Jones, Hillier and Comfort (2014) found little evidence of independent external assurance. The leading hotel chains will need to commission independent external assurance of their contributions to the SDGs or the credibility of their reporting of such contributions will run the risk of being undermined.

Without such independent external assurance, there is the danger, for example, of hotel groups being accused of what Dentsu Aegis Network (2018) described as 'SDG Wash', which has clear parallels with 'greenwash', the environmentally pejorative term used when green communication messages are deceptively used to promote the perception that a company's products, aims or 
policies are environmentally friendly. More specifically, the argument is that if 'companies use the SDGs in their communications to expand the corporate value and sales of their own company' then 'there is a danger that the company will receive criticism and suggestions for improvement from each stakeholder due to mistaken methods of communication' (Dentsu Aegis Network 2018). As such, Dentsu Aegis Network (2018) argued that SDG Wash damages both 'the relationship of trust between consumers and individual companies' as well as 'the appeal of the company as an investment and loan destination.'

The Relationships and Tensions between Business Imperatives and Sustainability

Finally, there are issues in that many of the selected hotel groups' commitments to the SDGs are couched in terms of business imperatives, not least efficiency and continuing growth, as well as sustainability. This was reflected, for example by Ray Bennett, Chief Global Officer, Global Operations at Marriott International, who argued incorporating environmental and social initiatives, including human rights awareness training, into our business is not only the right thing to do, it has a direct impact on our profits and beyond' (Marriot International 2017). On the one hand, this might be seen to resonate with the concept of shared value, which has been defined by Porter and Kramer (2011) as 'policies and practices that enhance the competitiveness of a company while simultaneously addressing the economic and social conditions in the communities in which it operates.' However, Crane et al. (2014) identified a number of weaknesses and shortcomings in the creation of the shared value model. They argued, for example, that the model 'ignores the tensions between social and economic goals', that it is 'naïve about the challenges of business compliance' and that it is 'based on a shallow conception of the corporation's role in society' (Crane et al. 2014). In justifying this assertion, they conclude that the model seeks to 'rethink the purpose of the corporation without questioning the sanctity of corporate self-interest' (Crane 2014). On the other hand, and arguably more contentiously, there are concerns, that the SDGs might be captured by corporate interests, and more specifically by corporate capitalism, to justify continuing economic growth despite concerns about the overconsumption of natural resources and the damaging social and environmental effects of such growth. Valenzuela and Bohm (2017), for example, argued that the term sustainability was effectively being 'captured by politic-economic elites claiming that rapid economic growth can be achieved in a way that manages to remain responsible to environment and society.'

\section{Conclusion}

While a number of trade organisations within the tourism and hospitality industry have argued that the industry can play a major role in contributing to the SDGs, this paper reveals marked variations in the ways in which the world's leading hotel groups have begun to address the SDGs. Two of the top ten hotel groups directly addressed the SDGs directly, albeit in different measure, six of the 
hotel groups claimed that the SDGs were integrated into their sustainability strategies, while the remaining two hotel groups did not address the SDGs. As such, the authors suggested that the world's leading hotel groups have some way to go if they are to play a leading role in contributing to the SDGs. The authors further suggested that in looking to fulfill that contribution, the leading hotel groups must focus more explicitly on the SDGs themselves, adopt a more comprehensive approach to drawing up their priorities for the SDGs, and address the issues of measurement, independent external assurance and the tensions between business imperatives and sustainability. That said, the leading hotel groups' contribution to the SDGs is clearly a work in progress and looking to the future, continuing to monitor and review that progress will provide a wealth of academic research opportunities for scholars in hospitality and tourism.

\section{References}

AccorHotels (2016) With Planet 21 AccorHotels Aims to Provide a Positive Hospitality Experience. Retrieved from https://bit.ly/2gcPIUx. [Accessed 7 December 2018].

AccorHotels (nd) Planet 21 Research. Retrieved from https://bit.ly/2M8nIrD. [Accessed 7 December 2018].

Bali Swain R (2018) SDG Measurement, Challenges and Policies. Retrieved from https://bit.ly/2Ro9ZCR. [Accessed 13 November 2018].

Crane A, Palazzo G, Spence LJ, Matten D (2014) Contesting the Value of Creating Shared Value. California Management Review 56(2): 130-154.

Dentsu Aegis Network (2018) SDGs Communication Guide. Retrieved from https://bit. ly/2ROjYRc. [Accessed 13 November 2018].

Global Reporting Initiative/United Nations Global Compact/World Business Council for Sustainable Development (2015) SDG Compass: The guide for business action on the SGDs. Retrieved from https://bit.ly/2e3EaHS. [Accessed 17 June 2016].

Hilton (2018) Travel with Purpose: 2017 Corporate Social Responsibility Report. Retrieved from https://bit.ly/2D8OxJi. [Accessed 4 December 2018].

Hilton Foundation (2018a) Sustainable Development Goals. Retrieved from https://bit.ly/ 2D7Yq9X. [Accessed 30 November 2018].

Hilton Foundation (2018b) Making the Global, Local: How the Sustainable Development Goals Can Be Implemented in the United States. Retrieved from https://bit.ly/2D7e ysu. [Accessed 4 December 2018].

Hyatt (2018) Corporate Responsibility at Hyatt. Retrieved from https://bit.ly/2TQwSf4. [Accessed 10 December 2018].

IHG (2018) UN Sustainable Development Goals. https://bit.ly/2FoYZid. [Accessed 4 December 2018].

International Tourism Partnership (2017) ITP Goals for 2030 Unite the Hotel Industry for Sustainable Future. Retrieved from https://bit.ly/2RoeLQN. [Accessed 2 December 2018].

Jones P, Hillier D, Comfort (2014) Sustainability in the Global Hotel Industry. International Journal of Contemporary Hospitality Management 26(1): 5-17.

Jones P, Hillier D, Comfort D (2017) The Sustainable Development Goals and the Tourism and Hospitality Industry. Athens Journal of Tourism 4(1): 7-18. 
International Tourism Partnership (2018) ITP Goals for 2030 Unite the Hotel Industry for a Sustainable Future. Retrieved from https://bit.ly/2RoeLQN. [Accessed 30 November 2018].

Jin Jiang Hotels (2017) Environmental, Social and Governance Report 2016. Retrieved from https://bit.ly/2SSgPNJ. [Accessed 10 December 2018].

Liverman D (2018) Geographical perspectives on development goals: constructive engagement and critical perspectives on the MDs ad the SDGs. Dialogue in Human Geography 8(2): 168-185.

MarketWatch (2018) Luxury Hotel Market 2018 Global Trend, Segmentation and Opportunities Forecast to 2013. Retrieved from https://on.mktw.net/2FAgOdz. [Accessed 8 January 2019].

Marriott International (2017) Marriott International Unveils Global Sustainability and Social Impact Commitments to Deliver Positive Change. Retrieved from https://bit.ly/ 2H90FOj. [Accessed 6 December 2018].

Melia Hotels International (2018) Integration of Sustainable Development Goals into Melia International. Retrieved from https://bit.ly/2VQmk1m. [Accessed 11 December 2018].

Morhardt JE (2009) Corporate Social Responsibility and Sustainability Reporting on the Internet. Business Strategy and the Environment 19(7): 436-452.

Moseley WG (2018) Geography and engagement with U N development goals: Rethinking development or perpetuating the status quo; Dialogues in Human Geography 8(2): 201-206.

NH Hotel Group (2018) Annual Report: Corporate Responsibility Report. Retrieved from https://bit.ly/2TI6rbc. [Accessed 11 December 2018].

Nightingale AJ (2018) Geography's contribution to the Sustainable Development Goals: Ambivalence and performance. Dialogue in Human Geography 8(3): 196-200.

Porter ME, Kramer MR (2011) Strategy and society: the link between competitive advantage and corporate social responsibility. Harvard Business Review 84(12): 7892.

PWC (2018) SGD Reporting Challenge SDG Prioritisation - Is Business on the Right Track. Retrieved from https://bit.ly/2FwXbTn. [Accessed 12 November 2018].

Shangri-La (2018) Corporate Social Responsibility. Retrieved from https://bit.ly/1yf9M Cf. [Accessed 11 December 2018].

Sultana F (2018) An (Other) geographical critique of development and SDG's. Dialogues in Human Geography 8(2): 186-190.

Tourism Review (2017) Top 10 Leading Hotel Groups. Retrieved from https://bit.ly/ 2QOocDY. [Accessed 8 December 2018].

United Nations (2018) About the Sustainable Development Goals. Retrieved from https://bit.ly/2jHjQmD. [Accessed 3 December 2018].

UN Division for Sustainable Development Goals (2018) Helping governments and stakeholders make the SGDs a reality. Retrieved from https://bit.ly/1BSEj9K. [Accessed 13 November 2018].

UN Framework Convention on Climate Change (2018) Achieving the Sustainable Development Goal through Climate Action. Retrieved from https://bit.ly/2rtx6wu. [Accessed 12 November 2018].

United Nations Global Compact (2018) Global Goals for People and Planet. Retrieved from https://bit.ly/2vbzbNN. [Accessed 3 December 2018].

United Nations World Tourism Organization and United Nations Development Programme (2017) Tourism and the Sustainable Development Goals - Journey to 2030. Retrieved from https://bit.ly/2IdR0Wc. [Accessed 4 December 2018]. 
World Tourism Organisation and the United Nations Global Compact Network Spain (2016) The tourism sector and the Sustainable Development Goals: Responsible tourism, a global commitment. Retrieved from https://bit.ly/2RRytng. [Accessed 2 December 2018].

Valenzuela F, Bohm S (2017) Against Wasted Politics: A Critique of the Circular Economy. Ephemera: theory and Politics in Organization 17(1): 23-60.

Wyndham Hotels and Resorts (2018) Travelling Together for a Better World. Retrieved from https://bit.ly/2ST6p0n. [Accessed 9 December 2018]. 